Nephron 1996;74:I-VII

\title{
Contents, Vol. 74, 1996
}

Founded 1964 by

G. Richet and G.E. Schreiner

NEl·HRON

\section{Editors}

G.M. Berlyne, Brooklyn, N.Y. S. Giovannetti, Pisa

Section Editors

Distinguished Scientists Lecture Series

J.C.M. Chan, Richmond, Va.

Seminars in Renal Physiology

F. Lang, Tubingen

Controversies in Nephrology

M.S. Oh, Brooklyn, N.Y.

Nephrology Grand Rounds.

Clinical Issues in Nephrology

E. Ritz; M. Zeier, Heidelberg

Pediatric Nephrology

N.G. DeSanto, Naples

Molecular Biology in Renal Diseases

F.P. Schena, Bari

Editorial Board

A. Adler, Brooklyn, N.Y.

A. Albertazzi, Chieti

G. Andres, Charlestown, Mass.

V.E. Andreucci, Naples

P.-O. Attman, Göteborg

M. Avram, Brooklyn, N.Y.

A. Avramides, Thessaloniki

R.R. Bailey, Christchurch

D.S. Baldwin, New York, N.Y.

P. Bálint, Budapest

G. Barsotti, Pisa

G. Becker, Parkville

J. Ben-Ari, Haifa

J. Bernheim, Kfar Saba

V. Beroniade, Montreal, P.Q.

O.S. Better, Haifa

M.M. Beyer, Brooklyn, N.Y

Ch.R. Blagg, Seattle, Wash. 
M.D. Blaufox, New York, N.Y

V. Bonomini, Bologna

W.A. Border, Salt Lake City, Utah

N. Brautbar, Los Angeles, Calif.

O.-E. Brodde, Essen

B. Broumand, Teheran

U. Buoncristiani, Perugia

E. Bourke, Brooklyn, NY.

F. Cantarovich, Buenos Aires

G. Capasso, Naples

H. Carroll, Brooklyn, N.Y.

C. Chaimovitz, Beersheva

J. Chanard, Reims

J. Churg, New York, N.Y.

J.W. Cobura, Los Angeles, Calif.

F.L. Coe, Chicago, 111.

B.D. Cohen, Bronx, N.Y.

G. D'Amico, Milan

M. de Broe, Edegem

N. Di Paolo, Siena

P.B. Disler, Palmerston North

E.J. Dorhout Mees, Izmir

T Drüeke, Paris

R. Dzúrik, Bratislava

S.N. Emancipator, Cleveland, Ohio

BT. Emmerson, Brisbane

G. Falcone, Pisa

RJ. Falk, Chapel Hill, N.C.

R.N. Fine, Stony Brook, N.Y.

P. Fröhling, Potsdam

J.-L. Funck-Brentano, Paris

P. Fürst, Stuttgart

M.H. Gault, St. John's

M. Ghavamian, Teheran

C. Giordano, Naples

I. Greifer, Bronx, N.Y.

N. Gretz, Mannheim

G.F. Guarnieri, Trieste

R. Gusmano, Genova

R. Habib, Paris

M. Hatano, Tokyo

W.H. Hörl, Vienna

S. Indraprasit, Bangkok

C. Jacobs, Paris

J.D. Jones, Rochester, Minn.

M. Kashgarian, New Haven, Conn. 
D.N.S. Kerr, London

CM. Kjellstrand, Edmonton

C.R. Kleeman, Los Angeles, Calif.

K.M. Koch, Hannover

H. Köhler, Homburg/Saar

F. Kokot, Katowice

K Kopp, Munich

J.D. Kopple, Torrance, Calif.

H. Kramer, Bonn

F. Krueck, Bonn

K. Kühn, Hannover

CM. Kunin, Columbus, Ohio

K.N. Lai, Hong Kong

E. Lieberman, Los Angeles, Calif.

F. Llach, Newark, N.J.

G. Lubec, Vienna

R.G. Luke, Cincinnati, Ohio

M.L. Maayan, Brooklyn, N.Y.

K. Maeda, Nagoya

N.P. Mallick, Manchester

H.H. Malluche, Lexington, Ky.

G. Maschio, Verona

S.G. Massry, Los Angeles, Calif.

J.-P. Méry, Paris

K.A. Miles, Cambridge

L. Minetti, Milan

P.A.F. Morrin, Kingston

B. Nikakhtar, Santa Monica, Calif.

K.D. Nolph, Columbia, Mo.

B.E.C. Nordin, Adelaide

I. Nussenzveig, São Paulo

K. Ohta, Nagoya

D.G. Oreopoulos, Toronto

T. Orlowski, Warsaw

A. Pasternack, Tampere

D.K. Peters, Cambridge

V.E. Pollak, Cincinnati, Ohio

C. Ponticelli, Milan

J.G. Porush, Brooklyn, N.Y.

H.G. Preuss, Washington, D.C.

G. Remuzzi, Bergamo

J.P. Revillard, Lyon

A. Salvetti, Pisa

M.M. Schwartz, Chicago, 111.

R. Shainkin-Kestenbaum, Kfar Saba

S. Shaldon, Montpellier 
R.A. Sherman, New Brunswick, N.J.

N. Siegel, New Haven, Conn.

S. Stefoni, Bologna

R.A. Stein, Manhattan, N.Y.

W.K. Stewart, Dundee

M. Strauch, Mannheim

J. Strauss, Miami, Fla.

G.E. Striker, Bethesda, Md.

L.J. Striker, Bethesda, Md.

W.N. Suki, Houston, Tex.

J. Takeuchi, Tokyo

I. Tareyeva, Moscow

A. Tejani, Brooklyn, N.Y.

N.M. Thomson, Melbourne

A. Tizianello, Genova

A. Vangelista, Bologna

R. Waldherr, Heidelberg

E.N. Wardle, Oxford

L.G. Wesson, Philadelphia, Pa.

K. zum Winkel, Heidelberg

H.A. Yatzidis, Athens

E.T. Zawada, Jr., Sioux Falls, S.Dak.

R. van Zyl-Smit, Cape Town

P. Zucchelli, Bologna

KÄRGER

S. Karger

Medical and Scientific Publishers Basel · Freiburg · Paris · London New York · New Delhi ·

Bangkok Singapore $\cdot$ Tokyo $\cdot$ Sydney

Drug Dosage

The authors and the publisher have exerted every effort to ensure that drug selection and dosage set forth in this text are in accord with current recommendations and practice at the time of publication. However, in view of ongoing research, changes in government regulations, and the constant flow of information relating to drag therapy and drug reactions, the reader is urged to check the package insert for each drug for any change in indications and dosage and for added warnings and precautions. This is particularly important when the recommended agent is a new and/or infrequently employed drug.

All rights reserved.

No part of this publication may be translated into other languages, reproduced or utilized in any form or by any means, electronic or mechanical, including photocopying, recording, microcopying, or by any information storage and retrieval system, without permission in writing from the publisher or, in the case of photocopying, direct payment of a specified fee to the Copyright Clearance Center (see 'Information for Readers and Subscribers').

(C) Copyright 1996 by S. Karger AG, P.O. Box, CH-4009 Basel (Switzerland) Printed in Switzerland on acid-free paper by Thür AG Offsetdruck, Pratteln

II

Contents Vol. 74, 1996 


\section{NEPHRON}

No. 1

Editorial Review

1 Betaines and Urinary Tract Infections

Chambers, S.T.; Lever, M.

Original Paper

11 Biocompatibility of Haemodialysis Membranes:

Haemodialysis-Related Leukotriene B4 and C4 Generation

Hornych, A.; Rémy, P.; Luong, N.; Aumont, J.; Bariéty, J.

19 A Study on Regulating Factors of Plasma Refilling during Hemodialysis

Iimura, O.; Tabei, K.; Nagashima, H.; Asano, Y.

26 Biocompatibility of a $1.1 \%$ Amino Acid-Containing Peritoneal Dialysis Fluid Compared to a $2.27 \%$ Glucose-Based Peritoneal Dialysis Fluid

Brulez, H.F.H.; Dekker, H.A.T.; Oe, P.L.; Verbeelen, D.; ter Wee, P.M.; Verbrugh, H.A.

33 Effect of Long-Term Low-Dose Aluminum-Containing Agents on Hemoglobin Synthesis in Patients with Chronic Renal Insufficiency

Lin, J.-L.; Kou, M.-T.; Leu, M.-L.

39 Lipocortin-1 Inhibits Proliferation of Cultured Human Mesangial Cells

Kim, S.B.; Yang, W.S.; Lee, S.O.; Lee, K.P.; Park, J.S.; Na, D.S.

45 The Treatment of Chronic Hemodialysis Vascular Access by Directional Atherectomy

Mizumoto, D.; Watanabe, Y.; Kumon, S.; Kato, H.; Haruta, Y.; Kudo, N,; Ito, K.; Ito, S.; Sakai, K.; Fukuzawa, Y.

53 5-Year Follow-Up of Patients Successfully Transplanted after Immunoadsorption to Remove Anti-HLA Antibodies

Higgins, R.M.; Bevan, D.J.; Vaughan, R.W.; Phillips, A.O.; Snowden, S.; Bewick, M.; Scoble, J.E.; Hendry, B.M.

58 Study of Kidney Rejection following Simultaneous Kidney-Pancreas Transplantation

Cofán, F.; Ricart, M.J.; Oppenheimer, F.; Vilardell, J.; Campistol, J.M.; Astudillo, E.;

Fernández-Cruz, L.; Carretero, P.

64 Glomerular Hypertrophy in Relapsing Minimal Change Nephropathy

Tóth, T.; Takebayashi, S.

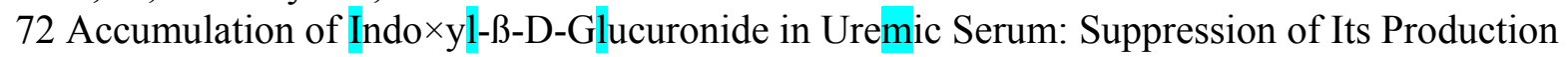
by Oral Sorbent and Efficient Removal by Hemodialysis

Niwa, T.; Miyazaki, T.; Tsukushi, S.; Maeda, K.; Tsubakihara, Y.; Owada, A.; Shiigai, T.

79 Increased Excretion of Tumor Necrosis Factor Alpha and Interleukin $1 ß$ in Urine from

Patients with IgA Nephropathy and Schönlein-Henoch Purpura

Wu, T.-H.; Wu, S.-C; Huang, T.-P.; Tsai, C.-Y.

89 Long-Term Effects of Intravenous $1 \alpha(\mathrm{OH}) \mathrm{D} 3$ Combined with $\mathrm{CaC} 03$ and Low-Calcium

Dialysis on Secondary Hyperparathyroidism and Biochemical Bone Markers in Patients on

Chronic Hemodialysis

Brandi, L.; Daugaard, H.; Nielsen, P.K.; Jensen, L.T.; Egsmose, C; Olgaard, K.

104 Hemodialysis Immediately after Acute Myocardial Infarction

Ifudu, O.; Miles, A.M.; Friedman, E.A.

110 Urinary Leucine Aminopeptidase Is a More Sensitive Indicator of Early Renal Damage in

Non-Insulin-Dependent Diabetics than Microalbuminuria

Bedir, A.; Özener, İ.Ç.; Emerk, K. 
$114 \mathrm{Na}+/ \mathrm{H}+$ Exchange in Patients with Mild Chronic Renal Failure Tepel, M.; Laukemper, S,; Zidek, W.

120 Serum Angiotensin-Converting Enzyme Activity in Patients with Endemic Nephropathy

Huskic, J.; Kulenovic, H.; Culo, F.

125 Ultrasonic Tissue Characterization of Renal Cell Carcinoma Tissue

Sasaki, H.·,Tanaka, M.; Saijo,Y.; Okawai, H.; Terasawa, Y; Nitta, S.; Suzuki, K.

131 Prevention of Posttransplant Peptic Ulcer by Misoprostol

Yang, C.W.; Lee, S.H.; Kim, Y.S.; Choi, E.J.; Chang, Y.S.; Yoon, Y.S.; Bang, B.K.

136 Renal Effects of Acute and Chronic Nitric Oxide Inhibition in Experimental Diabetes

Mattar, A.L.; Fujihara, C.K.; Ribeiro, M.O.; de Nucci, G.; Zatz, R.

144 Chronic Inhibition of Nitric Oxide Synthase in Heymann Nephritis

Uhlenius, N.; Tikkanen, I.; Tikkanen, T.; Miettinen, A.; Törnroth, T.; Fyhrquist, F.

150 Calcium Entry Stimulated by Swelling of Madin-Darby Canine Kidney Cells

Wöll, E.; Ritter, M,; Haller, T.; Völkl, H.; Lang, F.

158 Protective Action of Ulinastatin against Cisplatin

Nephrotoxicity in Mice and Its Effect on the Lysosomal Fragility

Yamasaki, F.; Ishibashi, M.; Nakakuki, M.; Watanabe, M.; Shinkawa, T.;

Mizota, M.

168

Renal Hemodynamic Response to Gradated Ureter Obstruction in the Pig

Hvistendahl, J.J.; Pedersen, T.S.; Jørgensen, H.H.; Rehling, M.; Frøkiær, J.

175

Content of Sulfur Amino Acids and Vitamin B6 and Related Enzyme Activities in Rats with

Chronic Renal Failure Fed a High Methionine Diet

Asagi, K.; Nakayama, M.; Kobayashi, M,; Awata, S.; Nakayama, K; Kodama, H.

183

Amino Acid Profiles and Muscle Protein Composition in Rats with a Reduced Renal Mass in the

Fed State

Cupisti, A.; Baker, F.; Bevington, A.; Brown, J.; Lock, C; Harris, K.P.G.; Walls, J.

189

Transforming Growth Factor-Beta in the Development of Rat Diabetic Nephropathy. A 10-

Month Study with Insulin-Treated Rats

Casaccia Bertoluci, M.; Schmid, H.; Lachat, J.-J.; Machado Coimbra, T.

197 Morphine Modulates Mesangial Immunoglobulin G Uptake in Rats with Antithymocyte

Serum-Induced Mesangial Cell Injury

Singhal, P.C.; Pan, C.Q.; Sagar, S.; Valderrama, E.; Stahl, R.A.K.

204

Increased Lipid Peroxidation by Rat Liver Microsomes in Experimental Renal Failure

Nagase, S.; Aoyagi, K.; Gotoh, M.; Hirayama, A.; Tomida, C; Shimozawa, Y.; Koyama, A.

209 Henoch-Schönlein Purpura and Membranoproliferative-Like Glomerulonephritis

Orfila, C; Lepert, J.-C; Modesto, A.; Pipy, B.; Sue, J.-M.

Case Report

KÄRGEH

E-Mail karger@karger.ch Fax+41 613061234 http://www.karger.ch

(C) 1996S. KargerAG, Basel 
The list of contents is available at: http://www.karger.ch/journals/nef/nefcont.htm

III

Letters to the Editor

214 Steroid-Responsive Hypercalcaemic Nephropathy in Diabetes mellitus Probably due to

Occult Sarcoidosis

Gupta, V.K.

216 Transperitoneal Removal of Osteocalcin, Calcitonin and Parathyroid Hormone in Patients

Treated by CAPD

Stefanovic, V.; Mitic, M.; Golubovic, M; Rajic, M.; Avramovic, V.; Ignjatovic, I.

218 Nephrotic Syndrome in Two Cases with Sickle Cell

Nephropathy

Seyrek, N.; Paydas, S.; Karayaylali, I.; Tuncer, I.; Sagliker, Y.

219 B2-Microglobulin as an Indicator of Interstitial Cell Infiltration

in IgA Nephropathy

Nitta, K.; Tsutsui, T.; Ozu, H.; Horita, S.; Naito, T.; Yumura, W.; Nihei, H.

221 99mTc-DMS Tubular Fixation in Balkan Endemic Nephropathy Patients

Rajic, M.; Bogicevic, M.; Ilic, S.; Stefanovic, V.

223 Guillain-Barré Syndrome after Renal Transplantation:

A Case of Clinical Success with Intravenous Immunoglobulin Therapy

Bouza-Piñeiro, P.; Pego, R.; Alonso, A.; de la Fuente, R.; Martul, E.V.

225 Calculation of an 'Adequate' Kt/V in the Individual Patient

Schück, O.; Kaälíková, J.

227 Nephrotic Syndrome Accompanying Hepatitis-B-Related

Liver Cirrhosis and Delta Hepatitis

Seyrek, N.; Paydas, S.; Kilic, H.; Karayaylali, I.; Sagliker, Y.

228 Effect of Beraprost Sodium, a PGI2 Analogue, on Proliferation

of Cultured Rat Glomerular Mesangial Cells

Makita, Y.; Sekizuka, K.; Wang, L.N.; Fukui, M.; Tomino, Y.

229 Renal Artery Aneurysm Manifested as Parapelvic Cyst on

Abdominal Sonography

Kwon, H.S.; Shin, S.J.; Yun, S.N.; Yang, C.W.; Chang, Y.S.; Bang, B.K.

230 Hepatitis E Seroprevalence in Dialysis in Southern Reunion

Island

Guiserix, J.; Finielz, P.; Ramdane, M.; Rajaonarivelo, P.

231 Acute Oliguric Renal Failure in a Patient with an Erysipelothrix

rhusiopathiae Bacteremia and Endocarditis

Fernández-Crespo, P.; Serra, A.; Bonet, J.; Gimenez, M.

232 Delayed Decubitus Perforation of the Bowel Is a Sword of

Damocles in Patients on Peritoneal Dialysis

Kagan, A.; Bar-Khayim, Y.

233 Reply to the Letter to the Editor by Kagan et al.

Thibodeaux, L.C.

234 Bleeding Diathesis in Uremic Patients Treated with Peritoneal

Dialysis: Role of Platelet Glycoproteins GPIb and GPIIb/llla

Abnormalities

Liani, M; Salvati, F.; Tresca, E.; Rubino, L.; De Meo, F.; Velussi, C; Cahen, R.; Golato, M. 
235 The Significance of Renal Tubular Deposition of

Apolipoprotein A1

Streather, C.P.; Scoble, J.E.

236 Ventricular Tachycardia due to Rapidly Changing Serum

Calcium Levels following Total Parathyroidectomy

Bacon, N.C.M.; Mason, P.D.

238 The Reproducibility of Cyclosporin-lnduced Hemolytic

Uremic Syndrome in a Renal Allograft Recipient

Ok, E.; Kursat, S.; Tokat, Y.; Cirit, M.; Tombuloglu, M.; Akcicek, F.

239 Bioenergetic Effects of Erythropoietin in Skeletal Muscle

Thompson, C.H.; Kemp, G.J.; Taylor, D.J.; Radda, G.K.

241 Heparin-Associated Thrombocytopenia during Continuous Venovenous Hemofiltration Berlot, G.; Lucchese, F.

243 Significative Improvement of Renal Function after Correction of Critical Renal Artery

Stenoses in Patients with Impaired Renal Function

Campieri, C; Giudicissi, A.; Dalmastri, V.; Pace, G; Neri, L.;

De Giovanni, P.; La Manna, G.; Moschella, M.R.; Martello, M.; Bonomini, V.

245 The Importance of Delay in Cannulation after Hemodialysis Vascular Access Surgery

Diskin, C.J.; Stokes, T.J.; Panus, L.W.

250 Effectiveness of Cysteamine and Mesna in Decreasing Intracellular Cystine Content in Cystinosis

Kernland, K; Lüthy, CM.; Wermuth, B.; Bianchetti, M.G.

242 Erratum

No. 2

Editorial

251 Nosocomial Hepatitis C in Dialysis Units

Sampietro, M.; Badalamenti, S.; Graziani, G.

Original Paper

$261 \alpha$-Ketoglutarate Application in Hemodialysis Patients Improves Amino Acid Metabolism Riedel, E.; Nündel, M.; Hampl, H.

266 An Index of Plasma Refilling in Hemodialysis Patients

Tabei, K; Nagashima, H.; Imura, O.; Sakurai, T.; Asano, Y.

275 Monocyte and Granulocyte CD11b/CD18, CD62L Expression and slCAM-1 Concentration in the Interdialytic Period

Thylén, P.; Fernvik, E.; Lundahl, J.; Lins, L.-E.; Jacobson. S.H.

283 Pharmacokinetics of Transperitoneal Insulin Transport

Widerøe, T.-E.; Dahl, K.J.; Smeby, L.C; Balstad, T.; Cruischank-Flakne, S,; Foiling, I.;

Simondsen, O.; Ahlmen, J.; Jørstad, S.

291 Oral Iron Absorption Test in Patients on CAPD: Comparison of Ferrous Sulfate and a Polysaccharide Ferric Complex

Tinawi, M.; Martin, K.J.; Bastani, B.

295 Effects of Parathyroid Hormone and 1,25(OH2)D3 on Protein Glycation in Moderate Uraemia

Lamb, E.J.; Fluck, R.J.; Venton, T.R.; Woodhead, J.S.; Raine, A.E.G.; Dawnay, A.B.St.J. 301 IgA Nephropathy with Poorly Developed Lymphoepithelial Symbiosis of the Palatine Tonsils 
Sato, Y.; Hotta, O.; Taguma, Y.; Takasaka, T.; Nose, M.

309 Effect of Cyclosporin Weaning on Glomerular Filtration Rate in Renal Transplantation Salas, M.; Loertscher, R.; Caro, J.J.

313 Clinical Effects of Intermittent, Intravenous Cyclophosphamide in Severe Systemic Lupus erythematosus

Martinelli, R.; Pereira, L.J.C; Santos, E.S.C; Rocha, H.

318 Mechanisms of Hyperuricemia in Cyclosporine-Treated Renal Transplanted Children Laine, J.; Holmberg, C.

324 Treatment of Posttransplant Lymphocele with Povidone-lodine Sclerosis: Long-Term Follow-Up

Rivera, M.; Marcén, R.; Burgos, J.; Arranz, M.; Rodriguez, R.; Teruel, J.L.; Ortuño, J.

328 Blood Rheology after Renal Transplantation

Koppensteiner, R.; Derfler, K.; Ehringer, H.

333 A Single-Base Mutation in Exon 31 Converting Glycine 852 to Arginine in the Collagenous Domain in an Alport Syndrome Patient

Kawai, S.; Nomura, S.; Harano, T.; Harano, K; Fukushima, T,; Wago, M,; Shimizu, B.; Osawa, G.

337 Clinical Pharmacokinetics of Oral Acyclovir in Patients on Continuous Ambulatory

Peritoneal Dialysis

Stathoulopoulou, F.; Almond, M.K.; DhiПon, S,; Raftery, M.J.

342 Leukocyte CD14 and CD45 Expression during Hemodialysis: Polysulfone versus

Cuprophane

Dhondt, A.W.; Vanholder, R.C; Waterloos, M.-A.F.; Glorieux, G.L.; Ringoir, S.M.G.

IV

Nephron Vol. 74, 1996

Contents

349 Inhibition of the Accumulation of Uremic Toxins in the Blood and Their Precursors in the Feces after Oral Administration of Lebenin ${ }^{\circledR}$, a Lactic Acid Bacteria Preparation, to Uremic Patients Undergoing Hemodialysis

Hida, M.; Aiba, Y.; Sawamura, S.; Suzuki, N.; Satoh, T.; Koga, Y.

356 Free Protein S Deficiency in Hemodialysis Patients due to Vascular Calcifications?

Perez-Mijares, R.; Payan-Lopez, J.; Guzman-Zamudio, J.L.; Sanchez-Angulo, J.I.; Gomez-

Fernandez, P.; Ramos-Diaz, M,; Alcala-Rueda, M.; Silgado-Rodriguez, G.; Hermosin-Ramos, L.; Almaraz-Jimenez, M.

361 Epidemiologic Analysis of Diabetic Patients on Chronic Dialysis

Sunagawa, H.; Iseki, K.; Nishime, K.; Uehara, H.; Toma, S,; Kinjo, K.; Fukiyama, K.

367 Cytomegalovirus Preemptive Therapy with Ganciclovir in Renal Transplant Patients Treated with OKT3

Gomez, E,; de Oña, M.; Aguado, S.; Tejada, F.; Nunez, M,; Portal, C; Diaz-Corte, C.; Sanchez, E,; Ortega, F,; Alvarez-Grande, J.

373 Increased Susceptibility to Membrane Lipid Pero×idation in Renal Failure Anderton, J.G.; Thomas, T.H.; Wilkinson, R. 378 VLDL and LDL Metabolism in Human and Rat Mesangial Cells

Krämer-Guth, A.; Nauck, M.; Quaschning, T,; Pavenstädt, H.; Wieland, H.; Schollmeyer, P.; Wanner, C. 
386 Characteristics of Anti-HCV Antibody-Positive Patients with Hepatocellular Carcinoma on Chronic Hemodialysis: Recommendation of Periodic Ultrasonography for Early Detection Sakai, Y.; Izumi, N,; Tazawa, J.; Uchihara, M.; Akiba, T,; Marumo, F.; Sato, C.

390 A Low-Nitrogen Low-Phosphorus Vegan Diet for Patients with Chronic Renal Failure Barsotti, G.; Morelli, E.; Cupisti, A.; Meola, M; Dani, L,; Giovannetti, S.

395 Pulmonary Dysfunction in Type 1 Diabetes in Relation to Metabolic Long-Term Control and to Incipient Diabetic Nephropathy

Schnack, C; Festa, A.; Schwarzmaier-D’Assié, A.; Haber, P.; Schernthaner, G.

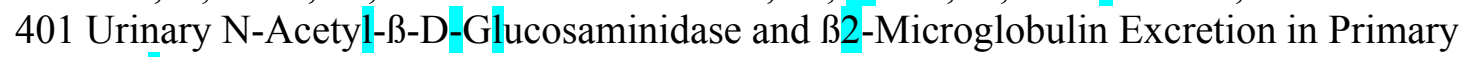
Nephrotic Children

Çahskan, S.; Hacibekiroglu, M.; Sever, L.; Özbay, G,; A

Case Reports

405 Hyperreninemia, Hypertension, and Congestive Heart Failure in Focal Interstitial Nephritis Matsui, A.; Ono, K,; Nakagawa, M.

409 Alpha-Fetoprotein-Producing Renal Cell Carcinoma with Increased Activity of N-

Acetylglucosaminyltransferase III

Aoyagi, Y,; Mori, S,; Naitoh, A.; Yanagi, M,; Suzuki, Y,; Suda, T,; Isokawa, O.; Igarashi, H,;

Takahashi, T.; Isemura, M,; Asakura, FE.

415 Nonocclusive Mesenteric Infarction in Continuous Ambulatory Peritoneal Dialysis

Korzets, Z.; Ben-Chitrit, S.; Bernheim, J.

Preliminary Communication

419 Reduced Renal Clearance of Furancarboxylic Acid, a Major Albumin-Bound Organic Acid, in Undialyzed Uremic Patients

Sato, M.; Koyama, M.; Miyazaki, T,; Niwa, T.

Commentary

422 Minimal Change Nephrosis and Allergy

Wardle, E.N.

Letters to the Editor

424 Immunogenicity and Efficacy of Hepatitis B Vaccination in Indian Chronic Renal Failure

Patients on Hemodialysis and after Renal Transplantation

Krishnamurthy, G.; Kher, V.; Naik, S.

426 Situs inversus: An Uncommon Extrarenal Association of

Alport's Syndrome

Rezaie-Jami, T.; Khoshsorour, M.R.; Islami, M.; Amir-Ansari, B.; Ganji, M.R.; Farhud, D.D.;

Broumand, B.

427 Ureteral Triplication with Contralateral Duplication

Srivastava, D.N.; Mukhopadhyay, S.; Agarwal, S.K.

429 Peritoneal Lavage Therapy for Severe Acute Pancreatitis after Renal Transplantation

Yagisawa, T.; Toma, H.; Takahashi, K.; Tanabe, K.; Tokumoto, N.; Iguchi, Y.; Teraoka, S.; Ota, $\mathrm{K}$.

431 Administration of Recombinant Erythropoietin Determines Increase of Peripheral

Resistances in Patients with Hypovolemic Shock

Allegra, A.; Galasso, A.; Siracusano, L,; Aloisi, C; Corica, F.; Laganà, A.; Frisina, N.; Buemi, M.

433 Continuous Hemofiltration in Children with Abdominal Complications of HemolyticUremic Syndrome 
Cavagnaro, F.; Ronco, R.; Verdaguer, M,; Diaz, J.; Lewin, L.; Cerda, M.

435 No Pathogenic Role of Enhanced Plasma IgA Binding Capacity to Fibronectin and IgA-

Fibronectin Aggregates in Henoch-Schönlein Purpura

Davin, J.-C; Li Vecchi, M.; Mahieu, P.

437 Rhabdomyolysis and Acute Renal Failure Associated with Gemfibrozil Therapy

Górriz, J.L;; Sancho, A.; Lopez-Martin, J.M.; Alcoy, E; Catalan, C; Pallardó, L.M.

439 Membranous Nephropathy Associated with Oxaprozin Treatment

Ogawa, M.; Ueda, S.; Hamano, Y.; Ito, K,; Saisho, H,; Akikusa, B.

441 Systemic Lupus erythematosus following Hepatitis B Vaccine

Guiserix, J.

442 Percutaneous Liver Biopsy Complications in Patients with

Chronic Renal Failure

Özdogan, M.; Özgür, O.; Boya«oglu, S.; Co $3 / 8$ kun, M.; Kart. H.; Özdal, S.; Telatar, H.

444 Evolution of Anemia of Chronic Renal Failure after the Treatment of Hyperparathyroidism Garcia-Canton, C.; Palomar, R,; Moreno, A.; Toledo, A.; Suria, S,; Esparza, N.; Rossique, P.;

Checa, M.D.

446 Nephrotic Syndrome after Norfloxacin

Hanson, B,; DHondt, A.; Depierreux, M.; Lustman. F.

447 Renal Infarction in a Patient without Underlying Diseases

Ikeda, Y,; Sakemi, T.; Kato, A.; Kudo, S.

449 A Case of Membranous Nephropathy Exacerbated after the Use of Hair Dye

Aburaya, J.

452 Uric Acid Transport in Fanconi Syndrome with Marked Renal Hypouricemia: Analysis

Using Pyrazinamide and Benzbromarone

Moriwaki, Y,; Yamamoto. T.; Takahashi, S,; Hiroishi, K.; Yamakita, J.; Nasako, Y.; Naito, Y.;

Higashino, $\mathrm{K}$.

454 Detection of Bence-Jones Proteinuria by a Modified Method

Ghorbani, G.; Maryoussef, P.; Ghods, A.

455 Increasing Incidence of Diabetic Nephropathy in Spain

Robles, N.R.; Cid, M.C.; Pizarro, J.L.; Sánchez-Casado, E.

457 Familial Membranous Lupus Nephritis in Brothers

Ha, T.S.; Lee, K.W.

459 New Prescription of Peritoneal Dialysis: Intermittent Ambulatory Peritoneal Dialysis

Okada, K,; Urae, J.; Takahashi, S.

462 Effects of Weight Reduction and Angiotensin-Converting

Enzyme Inhibition on IgA Nephropathy-Associated Proteinuria

Kuiper, J.J.

464 Renovascular Hypertension after Laparoscopic Adrenalectomy in a Patient with Adrenal

Adenoma

Wu, T.-H.; Tsai, S.-H.; Tsai, C.-Y.; Huang, T.-P.

Contents

Nephron Vol. 74, 1996

$\mathrm{V}$

466 Seasonal Changes in Vitamin A and B-Carotene Levels in Chronic Hemodialysis Patients Kavukçu, S.; Turkmen, M.; Erogiu, Y.; Soylu, A.; Çamsa , T.; Büyükgebiz, B. 
468 Anaphylactoid Reaction Induced by IMafamostat Mesilate in a Hemodialysis Patient Maruyama, H.; Miyakawa, Y.; Gejyo, F.; Arakawa, M.

$470 \quad$ Infectivity from Hydraulic Circuits of Individual Dialysate

Supply Systems

Guiserix, J.

471 Elevation of Interleuki 6 in the Dialysate Reflects Peritoneal

Stimuli and Deterioration of Peritoneal Function

Fujimori, A.; Naito, H,; Miyazaki, T,; Azuma, M.; Hashimoto, S.; Horikawa, S.; Tokukoda, Y.

473 Trichoderma Harzianum Peritonitis in Peritoneal Dialysis

Guiserix, J.; Ramdane, M.; Finielz, P.; Michault, A.; Rajaonarivelo, P.

475 Prevalence of Epstein-Barr Virus Antibody in the Chronic

Hemodialysed Population in the South of the Reunion Island

Guiserix, J.; Michault, A.; Ramdane, M.; Finielz, P.; Rajaonarivelo, P.

476 Needle Pricks in Dialysis Population

Al Shohaib, S.

477 Superoxide Dismutase as a Prognostic Criterion in IMephrotic

Syndrome

Noyan, A.; Dikmen, N,; Anarat, A.

478 Kostmann's Syndrome and IgA Nephropathy: An Unknown

Association

Tsimaratos, M.; Brunet, P.; Dussol, B.; Michel, G; Mege, J.L.; Casanova, P.; Jaber, K.; Burtey, S.; Picon, G; Berland, Y.

$479 \quad$ IgA Nephropathy in a Patient with Unilateral Renal Agenesis

Waga, S.; Kakizaki, Y.; Sugimoto, K,; Tanaka, H,; Yokoyama, M.

481 Severe Hyperparathyroidism Associated with Fibrous Dysplasia: A Case Report

A $\pi$ k, N.; Biriken, D.; Akpolat, T.; Sungur, C; Çoskun, C; Basoglu, T,; Keskin, M,; Sahin, M.;

Ögütcen Toller, $M$.

483 A Clinical Correlative Study of Bone Densitometric Changes in Hemodialysis Patients with Hyperparathyroidism

Adam, B,; A $\pi \mathrm{k}, \mathrm{N}$, ; Baßoglu, T; Akpolat, T,; §ahin, M.; Çoskun, C; Kandemir, T,; Bernay, 1.

485 Pregnancy and Renal Transplant

Al Shohaib, S.

486 Metastatic Germ Cell Tumor Presenting with Renovascular

Hypertension

Çelik, I.; Bađsta, I.; Akhan, S.; Erdem, Y.; Tekuzman, G.

488 Further Evidence for Nosocomial Spread of Hepatitis C Virus

Infection in Hemodialysis Units

Dimkovic, N.; Dragiðevic", P.; Lazic, N.; Radmilovic, A.

489 Hemolytic-Uremic Syndrome Associated with Acute

Campylobacter upsaliensis Gastroenteritis

Carter, J.E.; Cimolai, N.

490 Acute Renal Failure Complicating Nonfulminant Hepatitis A in

Childhood

Martino, R.; Casaulta Aebischer, C; Baehler, P.; Bianchetti, M.G.

491 Is Interdialytic Blood Pressure Profile Related to Structural

Changes of Arteries in Haemodialysis Patients? 
Fabbian, F.; Squerzanti, R.; Malacarne, F.; Cecchetti, E.; Cogliati, P.; Gilli, P. 493 Severe Lupus Cystitis with Obstructive Uropathy

Odeh, M.

495 Chronic Ambulatory Peritoneal Dialysis in a Patient with

End-Stage Renal Disease following Radiotherapy and Surgery for Transitional Cell Carcinoma Mcligeyo, S.O.; Kayíma, J.K.; Oliech, J.S.; Monda, S.M.

497 Wilson Cirrhosis Associated with Membranoproliferative Glomerulonephritis

Gündüz, Z.; Düßünsel, R.; Anarat, A.

499 Effect of Intravenous Recombinant Erythropoietin

Administration on Plasma and Erythrocyte Magnesium Concentrations in Patients on

Hemodialysis

Allegra, A.; Corica, F.; Ientile, R.; Naso, A.; Corsonello, A.; Montalto, G.; Castagna, L.; Buemi, M.

No. 3

Editorial Review

501 Tubular Dysfunction following Kidney Transplantation

Heering, P.; Degenhardt, S.; Grabensee, B.

Original Paper

512 Acute Renal Failure in Kidney Transplant Patients Treated with Interferon Alpha 2b for Chronic Hepatitis C

Rostaing, L.; Modesto, A.; Baron, E.; Cisteme, J.M.; Chabannier, M.H.; Durand, D.

517 Treatment of Postrenal Transplant Erythrocytosis.

Long-Term Efficacy and Safety of Angiotensin-Converting Enzyme Inhibitors

MacGregor, M.S.; Rowe, P.A.; Watson, M.A.; Rodger, R.S.C.; Junor, B.J.R.; Briggs, J.D.

522 Intraglomerular Deposition of Intact Cross-Linked Fibrin in IgA Nephropathy and HenochSchönlein Purpura Nephritis

Ono, T.; Muso, E.; Suyama, K,; Oyama, A.; Matsushima. H.; Yashiro, M.; Kuwahara, T.;

Toshida, H.; Kanatsu, K.; Sasayama, S.

529 Hyperlipidemia in Children: The Role of Uremia, Steroids and Cyclosporine Therapy

Singh, A.; Tejani, A. 536 Adenohypophyseal-Gonadal Dysfunction in Male Haemodialyzed

Patients before and after Subtotal Parathyroidectomy

Zofkovà, I.: Sotorník, I.; Kancheva, R.L. 541 The Spectrum of Endemic Renal Tubular Acidosis in the Northeast of Thailand

Vasuvattakul, S.; Nimmannit, S.; Chaovakul, V,; Susaengrat, W,; Shayakul, C; Malasit, P.; Halperin, M.L.; Nilwarangkur, S.

548 Growth Hormone Responses to Growth Hormone-Releasing Hormone and Clonidine before and after Erythropoietin Therapy in CAPD Patients

Díez, J.J.; Iglesias, P.; Sastre, J.; Méndez, J.; Selgas, R.; Gómez-Pan, A.

555 Decreased Serum Antioxidant Activity of Hemodialysis Patients Demonstrated by

Methylguanidine Synthesis and Microsomal Lipid Peroxidation

Nagase, S.; Aoyagi, K.; Hirayama, A.; Gotoh, M; Ueda, A.; Tomida, C; Kikuchi, H.; Takemura, $\mathrm{K}$; Koyama, A.

561 Leukopenia and Rheological Anomalies in Leukocytes during Hemodialysis in Patients with Chronic Renal Failure

Iijima, S.; Otsuka, F.; Takita, T.; Kikuchi, Y. 
567 Fractional Urea Clearance in Continuous Ambulatory Peritoneal Dialysis: Effects of Volume Disturbances

Tzamaloukas, A.H.; Murata, G.H.; Dimitriadis, A.; Voukiklari, S.; Antoniou, S.; Malhotra, D.; Kakavas, J.; Dombros, N.V.; Nicolopoulou, N.; Balaskas, E.V.

572 Complete Clinical Remission and Subsequent Relapse of Bronchiectasis-Related (AA)

Amyloid Induced Nephrotic Syndrome

Goldsmith, D.J.A.; Roberts, I.S.P.; Short, CD.; Mallick, N.P.

577 Inhibitory Effect of Adrenomedullin on Rat Mesangial Cell Mitogenesis

Segawa, K.; Minami, K,; Sata, T.; Kuroiwa, A.; Shigematsu, A.

580 Serum Levels of 3-Deoxyglucosone and Tissue Contents of Advanced Glycation End

Products Are Increased in Streptozotocin-lnduced Diabetic Rats with Nephropathy

Niwa, T.; Miyazaki, T.; Katsuzaki, T.; Tatemichi, N.; Takei, Y.

586 Minimal Change-Like Glomerular Alterations Induced by a Human Plasma Factor

Cheung, P.K.; Klok, P.A.; Bakker, W.W.

594 Morphological and Morphometric Changes in Mesothelial Cells during Peritoneal Dialysis in the Rabbit

Di Paolo, N.; Garosi, G.; Petrini, G.; Monaci, G.

600 Optimal Transport Parameters of the Inner Medullary

Collecting Duct in Interaction between Urine Concentrating and Urea Excreting Mechanisms: A

Computer Simulation Study

Hamada, Y.; Taniguchi, J.; Imai, M.

VI

Nephron Vol. 74, 1996

Contents

Case Reports

607 Successful Erythropoietin Treatment for Severe Anemia in Nephrotic Syndrome without Renal Dysfunction

Ishimitsu, T.; Ono, H.; Sugiyama, M.; Asakawa, H.; Oka, K.; Numabe, A.; Abe, M,; Matsuoka, H.; Yagi, S.

611 Combined Chemotherapy and Radiotherapy for Esophageal Carcinoma in a Hemodialyzed Patient. Long-Term Survival Rebibou, J.M.; Chauffert, B.; Dumas, M,; Mousson, C; Bone, M.C.; Tanter, Y,; Rifle, G.

Short Communications

613 Outcome of Commercial Renal Transplantation: Two Years Follow-Up

Mansy, H,; Khalil, A.; Aly, T.F.; Filobbos, P.; Al-Dusari, S.; Al-Shareef, Z.; Shlash, S.

617 The Frequencies of Hepatitis B Virus Markers and Hepatitis C Virus Antibody in Patients

with Glomerulonephritis

Paydas, S,; Seyrek, N.; Gönlüsen, G,; Sagliker, Y.

Letters to the Editor

687 Serum Erythropoietin and Erythropoiesis during Six Years after Kidney Transplantation

Goch, J.; Birgegârd, G; Wíkström, B.; Backman, U.; Wadström, J.; Danielson, B.G

694 Effects of Intraperitoneal Antibiotics on Human Peritoneal Mesothelial Cell Growth

Yen, C.-J.; Tsaí, T.-J.; Chen, H.-S.; Fang, C.-C; Yang, C.-C; Lee, P.-H.; Lin, R.-H.; Tsai, K.-S.; Hung, K.-Y.; Yen, T.-S.

701 AIDS-Associated Renal Tuberculosis 
Marques, L.P.J.; Rioja, L.S.; Oliveira, C.A.B.; da Rosa Santos, O. 705 Ranitidine Has No Influence on Tubular Creatinine Secretion van den Berg, J.G.; Koopman, M.G.; Arisz, L.

709 An Inhibition of Urinary Albumin Excretion by Protease Inhibitor in StreptozotocinDiabetic Rats

Ikeda. T.; Hoshino, T.

713 Influence of Isoelectric Point on Glomerular Deposition of Antibodies and Immune

Complexes

Woitas, R.P.; Morioka, T.

Case Report

620 Age at Renal Replacement Therapy in Autosomal Dominant

Pol $\gamma$ cystic Kidney Disease

Gonzalo, A.; Gallego, A.; Tato, A.; Ortuño, J.

621 Frequency of Helicobacter pylori Infection in Uremic

Hemodialyzed Patients with Antral Gastritis

Krawczyk, W.; Górna, E,; Suwala, J.; Rózyc, P.; Pawtowski, L.; Krzywicka, A.; Wieczerza, B.; Król, A.

720 Recurrent Secondary Hyperparathyroidism Due to Parathyroid Carcinoma: Usefulness of Ki-67 Immunostaining in the Diagnosis of a Malignant Parathyroid Tumor

Dionisio, P.; Stramignoni, E.; Passarino, G.; Pucci, A.; Valenti, M.; Berto, I.M.; Portigliatti

Barbos, M.; Cadario, A.; Gasparri, G.; Bajardi, P.

Short Communication

623

Are the Increased Lp(a) Levels in Hemodialysis Patients Related to Glucose Intolerance and Hemodialysis Duration?

Elisaf, M.; Siamopoulos, K.C.

724 Effects of Hand Dominance and Sleep Side Preference on Hemodialysis Vascular Access

Survival

Diskin, C.J.; Stokes, T.J.; Panus, L.W.

Letters to the Editor

No. 4

Editorial

625 Nutritional Markers and Survival in Maintenance Dialysis Patients

Pollock, C.A.; Ibels, L.S.; Allen, B.J.

Nephrology Grand Rounds. Clinical Issues in Nephrology Section Editors: Prof. E. Ritz and Dr.

M. Zeier, Heidelberg

642 Coronary Artery Disease in Dialysis Patients

Wizemann, V.

Original Paper

652 Platelet-Derived Growth Factor, Interleukin (IL)-1ß, IL-6, IL-6R and Tumor Necrosis

Factor-« in IgA Nephropathy.

An Immunohistochemical Study

Taniguchi, Y.; Yorioka, N.; Oda, H.; Yamakido, M. 
661

Influence of Urinary Calcium Concentration on Erythrocyte Morphology

Bonucchi, D.; Ballestri, M.; Bettelli, F.; Baraldi, A.; Gola, M.; Lucchi, L.; Lusvarghi, E.

668

Nifedipine Can Preserve Renal Function in Patients Undergoing Aortic Surgery with Infrarenal Crossclamping

Antonucci, F.; Calò, L.; Rizzolo, M.; Cantaro, S,; Bertolissi, M.; Travaglini, M.; Geatti, O.;

Borsatti, A.; D'Angelo, A.

674 Agreement between the Classical Urea Kinetic Model and Direct Dialysis Quantification:

Importance of Urea Rebound

Bosticardo, G.M.; Alloatti, S.

680

Intravenous Calcitriol Therapy Restores Reduced Antigen-Induced T-Lymphocyte Response in 1,25-(OH)2D3-Deficient Hemodialysis Patients

Antonen, J.; Saha, H.; Lagerstedt, A.; Krohn, K,; Pasternack, A.

729

Bisphosphonates Prevent the Hungry Bone Syndrome

Kumar, A.; Ralston, S.H.

730

Seroprevalence of Hepatitis E in Hemodialysis Patients in Turkey

Cengiz, K.; Özyilkan, E.; Coßar, A.M.; Günaydm, M.

731

Does Recombinant Human Erythropoietin Affect Plasma Lipids in Hemodialysis Patients?

Cengiz, K.

733

Kobe Earthquake and the Patients on Hemodialysis

Inui, A.; Inoue, H.; Uemoto, M.; Kasuga, M.; Taniguchi, H.

734 Antineutrophil Cytoplasmic Autoantibody-Positive Crescentic Glomerulonephritis

Associated with Thiamazole Therapy

Hori, Y.; Arizono, K.; Hara, S.; Kawai, R.; Hara, M.; Yamada, A.

736 Acknowledgement to the Reviewers 738 Author Index Vol.74,1996 742 Subject Index Vol. 74, 1996

The extended contents of issues 1 and 2 were made possible through the generous support of the 'Heinz Karger Memorial Foundation' in Basel.

Contents

Nephron Vol. 74, 1996

VII 